Please do not remove this page

RMIT

UNIVERSITY

\title{
An interactive job seeking system for vocational rehabilitation
}

McKay, Elspeth; Thomas, Trang; Martin, Jennifer

https://researchrepository.rmit.edu.au/esploro/outputs/9921861767301341/filesAndLinks?institution=61RMIT_INST\&index=null

McKay, E., Thomas, T., \& Martin, J. (2003). An interactive job seeking system for vocational rehabilitation. Journal of Computer Assisted Learning, 19(3), 396-398. https://doi.org/10.1046/j.0266-4909.2003.00041.x Document Version: Accepted Manuscript

Published Version: https://doi.org/10.1046/j.0266-4909.2003.00041.x

Repository homepage: https://researchrepository.rmit.edu.au

(C) 2003 Blackwell Publishing Ltd

Downloaded On 2023/04/26 23:08:02 +1000

Please do not remove this page 
Thank you for downloading this document from the RMIT Research Repository.

The RMIT Research Repository is an open access database showcasing the research outputs of RMIT University researchers.

RMIT Research Repository: http://researchbank.rmit.edu.au/

\section{Citation:}

McKay, E, Thomas, T and Martin, J 2003, 'An interactive job seeking system for vocational rehabilitation', Journal of Computer Assisted Learning, vol. 19, no. 3, pp. 396-398.

See this record in the RMIT Research Repository at:

http://researchbank.rmit.edu.au/view/rmit:6457

Version: Accepted Manuscript

Copyright Statement: (c) 2003 Blackwell Publishing Ltd

Link to Published Version:

http://dx.doi.org/10.1046/j.0266-4909.2003.00041.x 


\section{An enhanced interactive job seeking system for vocational rehabilitation: A work in progress report}

\section{Context}

Looking for work is complex. It involves a synthesis of decisions relating to many separate job seeking tasks. Typically these decisions require an initial discrimination of how an individual's skills match the job description. In addition, there are other contextual ingredients to weigh up when looking for a job; like whether the salary offered is acceptable and the location of the work. Finally and perhaps the most critical decision is the logistical analysis of arranging suitable transport. These job-seeking tasks are even more difficult for the disabled. Despite the Web Access Initiative (WAI) there are no Web-enabled work searching systems designed as vocational rehabilitation tools. This research note briefly describes a newly funded research project in progress that is designed to provide an interactive Web-enabled work searching resource for those undergoing vocational rehabilitation.

This project aims to capture the efficiencies of information communication technologies (ICT) to enhance job searching outcomes for people undergoing vocational rehabilitation programmes. There are real opportunities for human-computer interaction (HCI) to provide a flexible Web-based employment service that has distributed access for people who may experience difficulty in returning to work after a long absence. Multimedia technologies enable a multimodal approach to deal with the job seeking decisions. Through effective HCI, carefully scripted examples of job-seeking tasks can draw together disparate and difficult concepts. The environmental context of this research is unique, because it addresses the needs of people who suffer the negative cognitive effects from long-term unemployment.

The main objective of the research is to provide a context upon which the much needed collaborative educational research will flow involving corporate/ academia/government sector partnerships. The investigators have recently been awarded a university grant to build this user friendly Web-Portal that will bring together understanding employers, offering appropriate job opportunities, with unemployed people who require assistance in finding work.

\section{The Research Question}

It is all very well to devise an innovative learning system; complete with all the multimedia bells and whistles. However the investigators are cognizant of the need to allow for the pebble-in-the-pond phenomenon (Merrill 2002); where the central reason for creating a specialized Web-Portal needs to be examined first.

The major research question under investigation is: What is the most effective use of ICT in a Web-Portal that implements a work searching system for the long-term unemployed?

\section{Methodological Approach}

Web-based training combines three socio-technical developments: distance learning, computer-conveyed education and internet technologies (Horton 2000). The expected profile of the Web-Portal users indicates a commonality of long-term unemployment, representative of participants attending a wide range of community based vocational rehabilitation services. Database management techniques enable the investigators to maximize the HCI aspects into the Portal design, forming the largest component of the initial system development. The project will be conducted utilizing a phased project methodology: Concept development phase (completed): With 19\% of Australia's unemployed potentially disadvantaged in accessing information due to their disability, the investigators believe that the development and evaluation of a customized work search system for vocational rehabilitation is timely. Computers offer flexible and dynamic instructional/learning environments that depict minute detail or convey wholistic environments where imaginary events can be witnessed (Gibbons and Fairweather 1998). However due to the sensitivity of this customized job-seeking tool in a non-threatening and cognitively safe environment; the research methodology requires careful attention.

Scoping phase and Preliminary design (current): People construct knowledge about the working world through experiential processing; organizing these experiences into knowledge structures, and what is believed about those experiences (Jonassen, Meyers and McKillop 1996). In order to provide information about work-place environments in a non-threatening manner, the investigators will draw on educational strategies to implement seamless technological links between the Web-based communications and the Web-Portal (Rosenberg 2001). Therefore an important educative feature of the Web-Portal will be to create the relationship between the (re)-learning of basic work-skills (listening and following instructions), work-communities (social interaction and where to go for more information in the work-place), and workperformance expectations (competency based training). It is anticipated that the simulated work-placement VOD vignettes will work well (Pappo 2001). To maintain the validity of the testing instrumentation, the Web-Portal assessment tool will be calibrated using a representative sample of participants.

System development phase: When the design specifications have been completed, the Web-Portal will be built using the most appropriate authorware tools. For instance a decision must be made to utilize local software specialists for 
customized/home grown products (built inhouse), or to adopt the industry standard and utilize the comprehensive range of Macromedia, Inc.'s products like: V12 Database Engine, and Studio MX.

Execution phase: A pilot study will be executed over a four month period. It is assumed that arrangements can be made with people already known to the team to test the system during 2003, when components are progressively completed. The system will then be made available for use by a small select group of users. After each session on the system, the user will be interviewed by their case-worker, using the specially prepared research Questionnaire. By following this process, the user will not be stressed by new people external to their familiar surroundings and furthermore their privacy will be maintained.

Closure: A Closure Report will describe the data analysis and the pilot project results. The investigators will evaluate whether the project objectives/deliverables were achieved, within time and budget.

\section{Data Collection}

Due to the sensitivity of the privacy requirements expected for this type of work searching system, all interactivity modules will take place away from the computerized environment. For instance, a feedback and assessment will be conducted by the researchers. The investigators will only receive the data in hard copy format. The cognitive performance data will then be analysed using the QUEST interactive test-analysis system (Adams and Khoo 1996).

\section{Expected Methods of Data Analysis}

The research Questionnaire will be calibrated to ensure validity of the assessment instrumentation. This will be possible through a representative sample of participants for the calibration exercise. This means a small number of people will be required to test the complete system, including the post work search interview and assessment/feedback sessions. This calibration exercise is to maintain the validity of the testing instrument. Typical of the human factors involved in using the system include: vigilance, attention span, visual fatigue, concentration and coordination. Any weaknesses in the assessment items can be identified during this process. For instance: wrongly worded questions can be identified and corrected.

Item Response Theory describes the assessment method used by QUEST. It compares actual patterns of responses from the interaction of test-items with participants compared with a model pattern. This becomes the fit statistic. The main analytical tool for evaluating the QUEST data will be the statistical power analysis (Cohen 1977), which is a means analysis technique, based on testing the probability of a null hypothesis being incorrect.

\section{Expected Outcomes}

The researchers hope to develop a model that reflects the special needs of people recovering from the effects of longterm unemployment. This project will determine the industry needs for the design and implementation of a customized work searching system for disabled people in general, with a further focus on providing appropriate vocational rehabilitation. Furthermore, this project also serves to inform research Questionnaire development techniques. If successful, this pilot study will lead to work that informs government policy and practice for unemployed people with special needs, and assist Australia in meeting global Web accessibility standards.

\section{Reference List}

Adams, R. J. and Khoo, S.-T. (1996). Quest:The Interactive Test Analysis System. Melbourne, Australian Council for Educational Research.

Cohen, J. (1977). Statistical Power Analysis for the Behavioral Sciences. New York, Academic Press.

Gibbons, A. and Fairweather, P. (1998). Computer-Based Instruction: Design and Development. New Jersey, Educational Technology Publications.

Horton, W. (2000). Designing Web-Based Training. New York, Wiley.

Jonassen, D. H., Meyers, J.M. and McKillop, A. M. (1996). From Constructivism to Constructionism: Learning with Hypermedia/Multimedia Rather Than from It. Constructivist Learning Environments: Case Studies in Instructional Design. B. G. Wilson. New Jersey, Educational Technology Publications: 93-106.

Merrill, M. D. (2002). Pebble-in-the-Pond Model for Instructional Development. Performance Measurement, http://www.ispi.org/pdf/Merrill.pdf 41(7): 41-44.

Pappo, H. A. (2001). Simulations for Web-Based Training. Web-Based Training. B. H. Khan. New Jersey, Educational Technology Publications: 225-228.

Rosenberg, M. J. (2001). E-Learning: Strategies for Delivering Knowledge in the Digital Age. New York, McGraw-Hill. 